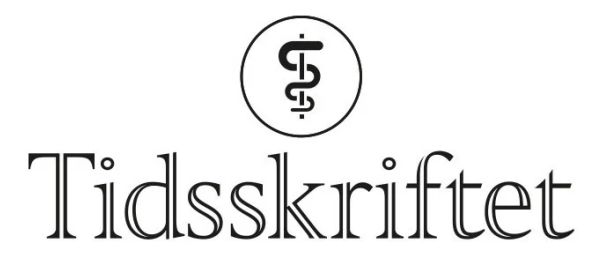

DEN NORSKE LEGEFORENING

\title{
Morfologisk unormale nøytrofile granulocytter ved covid-19
}

MEDISINEN I BILDER

\section{INGER ANNE TVEIT}

inger.anne.tveit@sshf.no

Laboratorieavdelingen

Sørlandet Sykehus, Arendal

Inger Anne Tveit er fagbioingeniør i hematologi og koagulasjon.

Forfatteren har fylt ut ICMJE-skjemaet og oppgir ingen interessekonflikter.

\section{HEGE ZAAR NIELSEN}

Laboratorieavdelingen

Sørlandet Sykehus, Arendal

Hege Zaar Nielsen er fagbioingeniør i hematologi og koagulasjon.

Forfatteren har fylt ut ICMJE-skjemaet og oppgir ingen interessekonflikter.

Inger Anne Tveit og Hege Zaar Nielsen har bidratt i like stor grad til denne artikkelen.
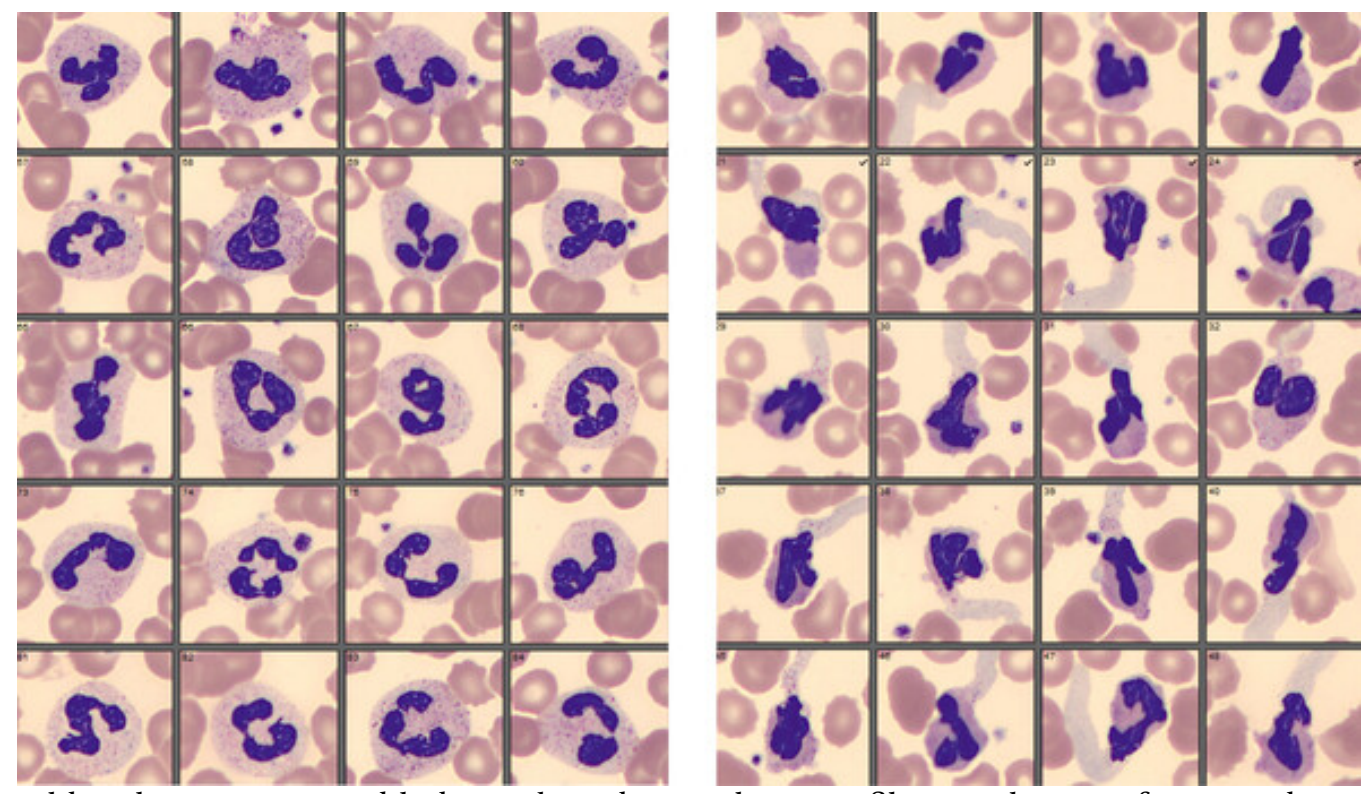

Bildet til venstre viser et blodutstryk med normale nøytrofile granulocytter, farget med May-Grünvald-Giemsa. Det er tatt innleggelsesdagen hos en pasient med covid-19. Bildet til høyre er tatt fem dager senere og viser at alle granulocyttene har fått en bemerkelsesverdig unormal morfologi. Få dager senere var cellebildet igjen normalisert. 
Dagens hematologiinstrumenter er programmert til å fange opp en rekke unormale funn i blodcellene. Ved abnormal morfologi vil instrumentet lage og farge blodutstryk samt klassifisere celler maskinelt. Det tas et utgangspunkt i 200 individuelle leukocytter som prefordeles i undergrupper.

Instrumentene varslet imidlertid ikke om abnormal morfologi på blodprøvene tatt fem dager etter innleggelse, men de ble i opplæringsøyemed mikroskopert. Granulocyttenes morfologi var påfallende. Mengden cytoplasma til de nøytrofile granulocyttene i blodutstryket var redusert betraktelig, og de inneholdt ingen vakuoler og lite granula. Cellekjernens struktur (segmentering), størrelse og fargeintensitet så derimot ikke ut til å være endret. I samtlige mikroskoperte nøytrofile granulocytter ble det observert en blå utposning fra cytoplasma som i mange tilfeller utgjorde en større del av cellenes totale volum. Noen steder kunne det også observeres granula i utposningen. Alle de nøytrofile granulocyttene hadde gjennomgående den samme unormale morfologien.

Blodutstryket til ytterligere fem pasienter med covid-19 ble fulgt opp, og hos to av dem fant vi samme fenomen. Observasjonene hos de tre med patologisk blodutstryk ble gjort på omtrent samme tidspunkt i sykdomsforløpet-3-4 uker etter symptomdebut. Sykdommens alvorlighetsgrad hos de tre pasientene var varierende. Den eneste åpenbare fellesnevneren var innleggelse og behandling $\mathrm{i}$ sykehus for covid-19. To av de tre pasientene lå på respirator under sykehusoppholdet. Alle tre hadde i tillegg nøytrofili og lymfopeni. Lymfocyttene hadde normalt utseende og var ikke aktiverte.

De nøytrofile granulocyttene utgjør førstelinjeforsvaret mot patogener (1). I senere tid er evnen til å danne såkalte nøytrofile ekstracellulære feller (neutrophil extracellular traps, NET) beskrevet hos denne cellegruppen. Dette er en prosess hvor cellene danner nettverk av tråder med kjerneholdig kromatin og proteiner for å omslutte patogenet for destruksjon, kalt NETose (므). Det er publisert histologiske bilder av nøytrofile granulocytter infiltrert i lungekapillærene hos covid-19- pasienter som muligens kan koples til denne prosessen (3). Alvorlig syke pasienter med covid-19 kan utvikle akutt lungesviktsyndrom (ARDS), og dette kan føre til et høyere nivå av nøytrofile ekstracellulære feller i plasma (3).

Det påfallende cellebildet hos samtlige av de nøytrofile granulocyttene hos de tre ulike pasientene kan muligens ha sammenheng med pågående NETose. Granulocytter har kort halveringstid og produseres kontinuerlig i beinmargen. Det kan forklare hvorfor cellebildet ble normalisert bare dager senere.

Pasientene har gitt samtykke til at artikkelen blir publisert.

Artikkelen er fagfellevurdert.

Vi vil takke Debbie Lee Clark, Kirsti Holden, Tove Ø. Lie, Anne Spurkland, Geir Rørbakken, Yngve Benestad og Thomas E. Hundhausen.

\section{LITTERATUR}

1. Iba T, Hashiguchi N, Nagaoka I et al. Neutrophil cell death in response to infection and its relation to coagulation. J Intensive Care 2013; 1: 13. [PubMed][CrossRef]

2. Brinkmann V, Reichard U, Goosmann C et al. Neutrophil extracellular traps kill bacteria. Science 2004; 303: 1532-5. [PubMed][CrossRef]

3. Barnes BJ, Adrover JM, Baxter-Stoltzfus A et al. Targeting potential drivers of COVID-19: Neutrophil extracellular traps. J Exp Med 2020; 217.-e20200652 doi: 10.1084/jem.20200652. [PubMed][CrossRef]

Publisert: 1. juli 2020. Tidsskr Nor Legeforen. DOI: 10.4045/tidsskr.20.0484

Mottatt 28.5.2020, første revisjon innsendt 16.6.2020, godkjent 23.6.2020.

(C) Tidsskrift for Den norske legeforening 2023. Lastet ned fra tidsskriftet.no 26. april 2023. 